\title{
The European Philanthropy Manifesto: 'clearly needed and a very good thing'?
}

\author{
Jenny Harrow \\ Centre for Charitable Giving and Philanthropy, Cass Business School City, University of \\ London
}

Tobias Jung

Centre for the Study of Philanthropy \& Public Good, University of St Andrews

\begin{abstract}
Launched in March 2019, the European Philanthropy Manifesto (EPM) argues for the introduction of a single market for philanthropy. Examining the historic precedents of that idea and the recommendations put forward in the EPM to achieve the single market, we critically reflect on the potential and shortcomings of the EPM.
\end{abstract}

Key words: foundations, European Union, philanthropy

Introduction

In 2013, the Chief Executive of the European Foundation Centre (EFC) declared himself likely to be dismayed if European Union (EU) member states could 'see eye to eye on a "pet passport" - which was clearly needed and is a very good thing - but could not soon agree on a European passport for foundations, namely the European Foundation Statute [EFS] that our [the foundation] sector has repeatedly called for over the past decade' (Salole 2013: NP). Dismay presumably set in quickly. Unlike extensive new regulations on the noncommercial movement of pets in the EU (European Commission 2013), a lack of consensus amongst the $28 \mathrm{EU}$ member states meant that the Proposal for a Council Regulation on the Statute for a European Foundation (European Commission 2012) was removed from the European Commission's (EC) 2015 legislative agenda. Recently, however, in May 2019, this 
Harrow, J and Jung, T, The European Philanthropy Manifesto: 'clearly needed and a very good thing'?, - post-peer-review preprint authors' version accepted for publication in Voluntary Sector Review

regulatory proposal was not only revived but at the heart of the 'European Philanthropy Manifesto' (EPM).

Arising from the joint Philanthropy Advocacy project of two umbrella bodies, the Donors and Foundations Networks in Europe (DAFNE) and the European Foundation Centre (EFC), the EPM calls for the introduction of a Single Market for Philanthropy (Philanthropy Advocacy 2019). Asserting that 'politicians should consider developing a supranational legal form for organised philanthropy' (Philanthropy Advocacy 2019: NP), the EPM makes four recommendations: recognition of, and engagement with, philanthropy; facilitation of crossborder support for philanthropy; facilitation and protection of philanthropy, and; strengthening joint grantmaking and co-investment opportunities (Philanthropy Advocacy 2019: NP).

The first recommendation, seeks 'better' recognition and promotion by EU policymakers and in EU treatise of the important role played by philanthropy in encouraging civil society, community cohesion and European values; it urges the application of Treaty Freedoms and EU Fundamental Rights to all foundation forms with the aim to unlock the full potential of institutional philanthropy for a democratic society. The second recommendation puts single market concepts, involving the free flow of (philanthropic) capital within Europe, at its centre. This recommendation's comprehensive and demanding coverage seeks the elimination of administrative barriers, the facilitation of tax-effective philanthropy across borders, and the abolition of foreign funding restrictions. As part of this, a supranational legal form for, and mutual recognition of legal personalities of, organised philanthropy are proposed. The third recommendation concerns a better operating environment, protective mechanisms for philanthropy and monitoring of EU and national legislation impinging on philanthropy. Geared towards ensuring compatibility of EU rights and freedoms and 'proportionate' mechanisms for addressing tax evasion, money laundering and counterterrorism financing rules, this recommendation also contains the sole, and somewhat isolated proposal for wider sectoral interests other than those of institutional philanthropy: 'We also call on politicians to work towards a fairer VAT deal for charities' (Philanthropy Advocacy 2019: NP). The fourth and final recommendation seems to shift from essential 'musts' to potential 'coulds' for politicians' steps. Ideas include introducing 
Harrow, J and Jung, T, The European Philanthropy Manifesto: 'clearly needed and a very good thing'?, - post-peer-review preprint authors' version accepted for publication in Voluntary Sector Review

financial instruments to act as catalysts for co-granting alongside philanthropy, de-risking institutional philanthropy's mission-related investments, as well as a call for an EU Justice, Rights and Values Fund aimed at complementing and leveraging philanthropic engagement in pressurised European civil societies (Philanthropy Advocacy 2019).

A series of questions arises from the EPM, its advocacy approach to European policymakers, and its political aims and expectations: To what extent does the EPM offer a new or a recycled policy direction for institutional philanthropy in Europe? What are the implications of the EPM's chosen emphasis on a single market for philanthropy and its links, if any, to the contested marketisation of philanthropy? What challenges might the EPM pose for the wider state of European civil society, occurring outside or beyond the foundation practice model? How does the EPM relate to global and regional philanthropy perspectives? Building and expanding on Jung's (2019) critical commentary on the EPM, our objectives for this paper are to explore these questions. We conclude that the EPM is not only a missed opportunity to utilise and engage with wider critically reflective discourse on foundations, but that, as a recasting of an older policy ambition by the foundation world, the EPM seems unlikely to succeed where previous initiatives have failed.

\section{Manifestos: roles and nature}

The EPM follows a long line of manifestos in philanthropy discourse. Recent examples from the UK include the Community Foundation Network's (2009) 'Manifesto for Community Philanthropists' or the Beacon Collaborative's (ND) 'Manifesto for Philanthropy'. Looking across these, and drawing on the wider political studies literature, a diverse spectrum of manifesto expressions and purposes can be identified: addressing internal and external audiences and aimed at achieving direct and indirect effects, manifestos can be voluntary or compulsory exercises; they can act as concrete or abstract expressions of identities and philosophies, as advertising, image projection and impression management, as contracts, promises or campaign plans, and as ways to build identities (Eder et al 2017, Harmel et al 2018, Ray 2007). Reviewing and synthesising these aspects, Clark and Bennie (2018: 255) arrive at a tripartite classification of ideal manifesto roles: contract/mandate manifestos geared towards office seeking; advertisement manifestos - aimed at promoting an 
Harrow, J and Jung, T, The European Philanthropy Manifesto: 'clearly needed and a very good thing'?, - post-peer-review preprint authors' version accepted for publication in Voluntary Sector Review

organisation or building credibility and future support, and; identity/principle manifestos associated with policy-seeking and the articulation of ideal situations. Of these, both the 'advertisement' and 'identity/principle' manifesto types have roles to play in organised interests' advocacy and lobbying. They provide a way of framing issues, articulating policy issues and offering desirable policy solution(s)(e.g. McGrath 2007).

Manifestos require advocates. While the concept of advocacy carries with it the connotation of acting on others' behalf, that of lobbying may or may not convey a sense of self-interest; for both, the prominence of interests working in coalitions is critical (Klüver 2013, Weible et al 2019). As the European discourse on civil society and civil dialogue is shaped by institutional interests, suiting some institutions better than others, (Smismans 2003) and as foundations' participation in EU policymaking for regulatory transactions appears most likely where individual appraoches are too costly (Perez 2019), it is unsurprising to find philanthropic foundations coming together to try and contribute to shaping their European policy landscape. To this end, the EPM provides foundations with an opportunity to set boundaries, frame the corresponding policy contexts and offer desirable solutions through a foundation lens.

\section{EPM: back to the future?}

In a brief 'what', 'why' and 'how section preceding its recommendations, the EPM refers to the identification of 'new opportunities to help shape and protect philanthropy's operating space' by the joint DAFNE-EFC study 'Enlarging the Space for European Philanthropy' (Philanthropy Advocacy 2019). The report commissioned for this study"explores possible future policy avenues that may exist to facilitate philanthropy in Europe' (Breen 2018: 3) and provides a critical basis for the DAFNE-EFC policy platform. Looking at three overarching areas - legal/regulatory measures, fiscal measures, and guidance/soft laws - the work points to longstanding obstacles in European non-profit regulation, misperceptions relating to counter-terrorism financing and money laundering, the need for soft-law mechanisms at national and European levels, and major challenges arising from incompatible and conflicting laws and practices at national and EU levels (Breen 2018). It is the drawing together of alternative routes to enhancing the philanthropic space by this review that 
Harrow, J and Jung, T, The European Philanthropy Manifesto: 'clearly needed and a very good thing'?, - post-peer-review preprint authors' version accepted for publication in Voluntary Sector Review

enables its commissioners to assess that it provides 'new opportunities' for European action.

A timely boost to - or reflection of - Breen's (2018) work was subsequently gained from the EC's Expert Group on Foundations, Venture Philanthropy and Social Investments (European Commission Directorate-General for Research and Innovation 2018). Looking at 'research and innovation' foundations, this reported on suitable framework conditions to support those foundations' progress. Its recommendations included better definitional clarity on foundations, as well as enhancement of cross-border giving and philanthropic investment by philanthropic foundations. Highlighting that '[o]ne of the first obstacles that the Expert Group had to tackle was - and is - the diversity in national legal regulations regarding foundations' (European Commission Directorate-General for Research and Innovation 2018: 14), its first recommendation to the EC and member states was nevertheless altogether more cautious: the commissioning of 'a feasibility study exploring the possibility of implementing a supranational legal form for institutional philanthropy which can be used as an instrument for cooperation with the EC' (European Commission Directorate-General for Research and Innovation 2018: 18).

In some ways, the combined insights of these reports do offer new opportunities claimed by the EPM, particularly in terms of soft, expert-led, lobbying. However, it is also useful to examine the EPM's recommendations from a historical perspective. Here, the underlying ideas and ideals associated with the EPM's recommendations seem to go back at least to 1993, when the EC started to explicitly discuss issues related to foundations' forms and cross-border activities (Alliance 2014). Subsequently, a number of catalytic developments progressing the debate occurred around 2000 in Germany. These included, an international conference on European foundation law organised by the University of Kiel's Max Planck Institute of Foreign and Comparative Law, as well as the Bertelsmann Foundation's work towards compiling a reference book on European foundations (see Schlüter et al 2001) and the Foundation's subsequent support for the design of a Statute for a European Foundation form (Moosmann 2007), a collaborative project that included two other German foundations - ZEIT Stiftung Ebelin and Gerd Bucerious - and an Italian one - Compagnia di San Paolo (Hopt et al 2008). Bearing in mind the diversity and complexity of the European 
Harrow, J and Jung, T, The European Philanthropy Manifesto: 'clearly needed and a very good thing'?, - post-peer-review preprint authors' version accepted for publication in Voluntary Sector Review

foundation landscape, this work took several years before those involved 'finally reached a common understanding on the wording and commentary of the Statute' (Moosmann 2007: 128-29). The resulting report tried to simultaneously offer a comparative legal perspective on national foundations laws and propose a European Foundation Statute (Moosmann 2007).

Alongside, and with other organisations such as the EFC also working on the idea of a European foundation form (Moosmann 2007), the idea of a European Foundation Statute was taken up by the EC; the latter identified an accompanying needs assessment as a medium term priority in the EU Company Law and Corporate Governance Action Plan adopted in 2003 (Hopt et al 2008). Following public consultation, the EC launched a feasibility study in November 2007. This was jointly carried out by the Max Planck Institute for Comparative and International Private Law and the University of Heidelberg (see Hopt et al 2008). Responsive to evidence that foundations encountered numerous obstacles when seeking to operate transnationally, proposals included a new European legal form, which foundations across the EU with a public benefit purpose would be able to opt for; a form to exist in parallel with domestic foundations, and recourse to this 'European Foundation' form entirely voluntary (European Commission 2009).

Drawing up an 'own-initiative opinion', the European Economic and Social Committee (EESC) in 2010 considered the development of a European Foundation Statute (EFS) a necessity (Sepi 2010) and recommended its adoption to the EC in 2012 (Nillsson 2012). Scholarly analysis broadly welcomed the development, but also highlighted numerous issues. These included questions relating to the harmonisation of member states' third sector regulations and laws (Rossi 2014), whether organisations could actually find statute law capable of creating the legally enabling environment for cross-border working that they sought (Breen 2008), and the extent to which proposed EFS provisions would be robust enough (Breen 2013). In the end, the EFS idea was parked as eight countries (the UK, Netherlands, Austria, Denmark, Estonia, Germany, Portugal and Slovakia) rejected either the initiative per se or the proposed text accompanying it (Alliance 2014, Moss 2014). 
Harrow, J and Jung, T, The European Philanthropy Manifesto: 'clearly needed and a very good thing'?, - post-peer-review preprint authors' version accepted for publication in Voluntary Sector Review

Commentary by the EFC (2014: NP) on 'the somewhat secretive character of negotiations' that surrounded that decision complained about 'the perversity of unanimity decisionmaking' that allowed a minority of countries to object the initiative (Salole cited in Alliance 2014). One conclusion was that 'any further initiative for a pan-European foundation statute would have to start from scratch' (Hartnell and Milner 2015: NP). Whether the EPM's 2019 policy content offers such a start remains unclear. With the case for EU politicians to consider development of a supranational legal from for organised philanthropy previously well-trodden, at best, the EPM seems 'new-ish' in the identification of alternative routes within existing EU rules for nearing, if not reaching, the single statute goal. Other than that, the EPM's novelty seems to be in style rather than substance by rebranding previous discussions as being all about the creation of a 'Single Market for Philanthropy'.

\section{EPM: a single market for philanthropy?}

At the EPM launch in Brussels, the EFC's chair was emphatic: 'It is only in the presence of a favourable environment that institutional philanthropy can fully perform its role of building social capital: an essential 'glue' in today's Europe, given the fragmentation caused by centrifugal forces and by an increasing disconnect between citizens and institutions (Lapucci cited in DAFNE 2019: NP). This contextualises the need for a 'Single Market for Philanthropy' that the EMP presents. Its implications, however, are not straightforward.

A key tension in the evolution of a single market is that it simultaneously represents a legal and a political process: legally it necessitates removing inter-state and national barriers and prohibitions as well as the harmonisation of laws and regulations, while political reality means that vested interests of national governments, professional associations and individual organisations will be at play (McGee and Weatherill 1990). Although the single market concept has been, and continues to be, essential for European integration, the agenda for developing and deepening it remains problematic: its political legitimacy has to be controlled and seized continuously and it has 'to be accepted that the single market is not the slogan that moves voters' (Pelkmans 2016: 1111). While appealing in theory, as a recent special issue on 'rethinking the European social market economy' highlights, practical guidance on managing the normative, historical and legal tensions and challenges inherent 
Harrow, J and Jung, T, The European Philanthropy Manifesto: 'clearly needed and a very good thing'?, - post-peer-review preprint authors' version accepted for publication in Voluntary Sector Review

in a single market idea at both European and general level remain complex (Claasen et al 2019).

If the single market is the EU's core asset, then that concept's attention-grabbing abilities are important, for good or ill. The terminology of markets alone may flag up warnings to those for whom simplistic linkages between markets and civil society are problematic (see Sandel 2013). More broadly, it appears particularly relevant in relation to the debate about philanthropy's 'financialisation' (Thümler 2016), where business and financial sector ideas, ideals and implements are transferred - often unreflectively - to the field. Accompanied by an emphasis on efficiency and effectiveness, an over-emphasis on philanthropic actors as market operatives thus has the potential to lead foundations to risk-aversion, their prioritising of 'safe' investments and accentuating of easy to reach targets, curbing philanthropy's risk-taking and innovative appetite.

It is not suggested that the EPM represents the kind of 'marketisation of philanthropy' critiqued by Nickel and Eikenberry (2009: 974) as a depoliticisation 'of the relationship between the market and the negative impacts it has on human wellbeing', thereby reducing philanthropy's potential for major social changes. However, the EPM's approach resonates with the argument that 'social marketisation' is a route to policy influence among civil society organisations generally (Han 2017), the tendency of using entrepreneurial and marketed strategies by civil society organisations in their survival, growth and interactions with government. In this case, too, then the EPM's promoters might be perceived as sellers of mature wine in as-new bottles.

Calling for a single market for philanthropy, albeit vaguely and in an appealing manner, also has a functional logic about it. It draws on the EU's most recognisable characteristic, implying that the single market should be extended and be more inclusive, reaching beyond what has been achieved so far. That organisational philanthropy, so treated, would provide an essential social 'glue' for an EU under pressure of fragmentation also presents the single market for philanthropy as a rescue remedy for the European project. Here, and potentially ascribable to the prominent Germanic roots of and contributions to the original EFS idea, the question arises whether the EPM's integrative rhetoric and reasoning resonates with 
Harrow, J and Jung, T, The European Philanthropy Manifesto: 'clearly needed and a very good thing'?, - post-peer-review preprint authors' version accepted for publication in Voluntary Sector Review

wider socio-political developments across the EU. Maybe, just like the actual colour scheme of the EPM itself, that perspective is somewhat rose-tinted.

\section{EPM: wider challenges?}

Whether or not a single market for philanthropy chimes with contemporary socio-political discourse, paradoxically, it might also face opposition from the philanthropic sector more broadly, from those lying outside the foundation field, from those who would also welcome the 'better protection' that the EPM seeks for philanthropic foundations alone. Essentially, from those types of organisations through which grant making foundations are able to achieve their aims. Why should those who do, rather than predominantly donate, not also be 'cherished and stimulated' if not 'rewarded persistently' (Philanthropy Advocacy 2019: NP) as foundations hope for themselves?

Being necessarily excluded from the EPM by virtue of 'being other than a foundation' may not itself be the issue, but rather the special and preferential treatment that seems to be sought by the foundation field. Although there is some degree of limited recognition of wider spheres of civil society action - e.g. 'philanthropy, alongside the wider civil society, plays a key role in defending and promoting the values enshrined in Article 2 of the EU Treaty (Philanthropy Advocacy 2019: NP)' - it remains philanthropy's important role in supporting civil society and community cohesion that is to the fore in seeking politicians' and policymakers' attention.

A key related question concerning the EPM is whether it engages with critiques as well as praise of philanthropy to strengthen its case. Here, if we consider that etymologically a manifesto refers not just to 'a public declaration' but also to 'proof' or 'a piece of evidence', the short answer is no. While the brevity and sought-after impact of manifestos as declarations do not warrant detailed presentation of contrarian views, at least some engagement in the EPM with foundation critiques as well as virtues could have produced more nuanced rhetoric, thereby widening the EPM's likely support. Instead, the document's rhetoric blurs boundaries; it oscillates between philanthropy in general, individual philanthropy and institutional expressions of philanthropy, i.e. foundations, thus conflating 
Harrow, J and Jung, T, The European Philanthropy Manifesto: 'clearly needed and a very good thing'?, - post-peer-review preprint authors' version accepted for publication in Voluntary Sector Review

diverse accompanying debates. These range from the spectrum of characteristics within the foundation field itself (Jung et al 2018) to engaging with the wider 'canon of concerns' that has been put forward in the literature: from questions about the origins and size of foundations funds, to foundations' unelected and undemocratic nature, their elite composition and influence, and the cultural imperialism and dominance that have been associated with foundations' activities (Jung and Harrow 2019). Instead, foundations are portrayed as possessing 'an outstanding set of expertise, deep knowledge and excellent stakeholder networks', as being in need of being 'cherished, stimulated and rewarded persistently', as making 'unique' contributions to society (Philanthropy Advocacy 2019).

Even without delving into academic debates on these issues, popular reactions to philanthropic contributions following the recent Notre Dame disaster provide some indications that the EPM's rhetoric of 'unleashing' philanthropy and its 'unique' contribution can easily be perceived in a more negative light: 'for those who care to look, there is plenty here that is ugly' (Chakrabortty 2019), 'millions for Notre Dame, nothing for Les Misérables' (Chrisafis 2019). Thus, being unreflective of socio-political critiques of foundations and indiscriminate in its applauding philanthropy, the EPM easily provides ammunition for, and plays straight into the hands of, populist critics. Bearing in mind the long history of popular and populist foundation critiques, that is unfortunate. Furthermore, it fails to ignore that the call for stronger political attention, recognition and integration can easily come with stronger political steerage and outside control and direction (Harrow and Jung 2015).

\section{EPM: global and regional philanthropy perspectives?}

The emphasis on the European dimension of philanthropic foundations coincides closely with the first 'Global Philanthropy' report on foundations. Alongside regional considerations, this offers a detailed country-based analysis and concludes that existing information on foundations 'is often anecdotal, incomplete and sometimes inconsistent' (Johnson 2018: 8). Furthermore, the foundation form's relative distinctiveness in European philanthropy is challenged in a mapping of European philanthropy. This argued that although the foundation sector is flourishing, 
Harrow, J and Jung, T, The European Philanthropy Manifesto: 'clearly needed and a very good thing'?, - post-peer-review preprint authors' version accepted for publication in Voluntary Sector Review

'[t]here is no one-size-fits-all portrait of the European philanthropist or donor, nor are there dominant models...a wide variety of profiles, motivations and practices exist. Philanthropy is being globalised, trade is intensifying and boundaries are becoming blurred. However, as in other areas, this globalisation is accompanied by a strengthening of national identities and characteristics' (Fondation de France and Centre d'Étude et de Recherche sur la Philanthropie 2015: NP).

Alongside, the question arises how wide - or how restricted - are understandings about 'Europe' in philanthropy policy development? The European Edition of 'The Global Philanthropy Environment Index' (IUPUI Indiana University Lilly Family School of Philanthropy 2018) takes a wide sweep, examining thirty countries, including Russia and Turkey. Measuring regulatory, political, and socio-cultural environments through a standard instrument completed by country-based experts, this Index relates to philanthropic organisations in the broadest possible sense, including volunteering and charities and informal organisations that seek as well as provide funding. Here, it seems that the EPM's understanding of philanthropy - while taking steps to accommodate individual giving seems to exclude the potential of expatriate remittances, widely considered an essential part of philanthropic activities (Kabir and Stirrat 2018). Such issues collectively reiterate that the EPM's repeat reference to philanthropy's and foundations' unique contributions warrants further exploration, that the value of more inclusive perspectives on foundations' positions vis-à-vis broader civil society is indicated, and that civil societies' development in the variety of 'Europes' is the shared, collective responsibility of individuals, groups and communities, rather than resting predominantly on foundations, supported by supranational governmental regulation.

\section{Conclusions}

The EPM's policy premises are that a particular legislative recognition of foundations' roles in the EU is essential for philanthropy's thriving, that an earlier (unsuccessful) proposal is the proper model for this purpose, and that the concept of the 'single market' is the best 
Harrow, J and Jung, T, The European Philanthropy Manifesto: 'clearly needed and a very good thing'?, - post-peer-review preprint authors' version accepted for publication in Voluntary Sector Review

basis for this model's operation. Notwithstanding different philanthropic traditions coexisting across EU member states, the EPM envisages that philanthropy's full potential still requires to be 'unleashed', that the leveraging of 'the impact of donors' and foundations' spending' is achieved by elevating foundations' importance, and that cogranting and co-investing between European foundations and the EU is a goal for European philanthropy in its own right.

Within the EPM as a policy proposal there is much to debate. Topics include whether the undoubted problems in cross-border working are that central to philanthropy's European presence, to whether foundations' (undoubted) achievements require such prominent 'cherishing' and 'support', and how all of this relates to the critiques and concerns that have also long accompanied foundations' work. Thus, the EPM's case that institutional philanthropy is an 'untapped potential' needs to be approached with great caution. When approached from that perspective, Breen's work (2018) remains illustrative of Smismans' (2003: 473) argument that the EU's civil society and civil dialogue discourse 'suits some institutions better than others'.

Collectively, the EPM looks to a pan-European solution to the challenges of expanding one particular form of philanthropic action. While originally 'prepared for the European elections' (European Foundation Centre, 2018, p. NP), it is difficult to see if its technical solutions or single market branding are likely to have greater effect than previous, extensive, efforts. Whether the proposals and core regulatory formula in the EPM are, like European pet passports - 'clearly needed and a very good thing' - remains to be determined or disregarded in the future: they did not, as we now know, appear to figure in European parliament elections in May 2019. Meanwhile, along with foundations, other components of the European philanthropy spectrum such as social enterprises and venture philanthropy organisations have already been part of recent EU dialogues, ahead of the proposed EU Multiannual Financial Framework (MFF) 2021-2027 (European Venture Philanthropy Association ND).

At present, the EPM's concerns also appear somewhat at odds with wider considerations of how G20 countries can 'achieve and maintain an enabling environment for civil society', 
Harrow, J and Jung, T, The European Philanthropy Manifesto: 'clearly needed and a very good thing'?, - post-peer-review preprint authors' version accepted for publication in Voluntary Sector Review

with commentators suggesting that 'much of the current impasse results foremost from outdated and increasingly ill-suited regulatory frameworks that fail to accommodate a much more diverse and expanded set of civil society organizations' (Anheier et al 2019: 1). As such, and at best, the EPM's advocacy amongst EU politicians and the new Commission for deepening the single market concept primarily for foundation-based philanthropy appears to be, just like deepening the single market per se, 'a tall order' (Pelkmans 2016: 1111). 
Harrow, J and Jung, T, The European Philanthropy Manifesto: 'clearly needed and a very good thing'?, - post-peer-review preprint authors' version accepted for publication in Voluntary Sector Review

\section{References}

Alliance (2014), Setback for European Foundation Statute as EU Member States fail to agree.

Anheier, H., Lang, M.and Toepler, S. (2019) 'Civil society in times of change: shrinking, changing and expanding spaces and the need for new regulatory approaches', Economics, 13(2019-8).

Beacon Collaborative (ND) A Manifesto for Philanthropy, https://www.beaconawards.org.uk/manifesto/.

Breen, O. (2008) 'EU Regulation of Charitable Organizations: The Politics of Legally Enabling Civil Society', International Journal of Not-for-Profit Law, 10(3): 50-78.

Breen, O. (2013) 'The European Foundation Statute Proposal: Striking the Balance between Supervising and Supporting European Philanthropy?', Nonprofit Policy Forum, 5(1): 543.

Breen, O. (2018) Enlarging the Space for European Philanthropy, Brussels: UCD Sutherland School of Law, European Foundation Centre, Donors and Foundations Networks in Europe.

Chakrabortty, A. (2019), The billionaires' donations will turn Notre Dame into a monument to hypocrisy. The Guardian.

Chrisafis, A. (2019), Millions for Notre Dame - but nothing for us, say gilets jaunes. The Guardian.

Claasen, R., Gerbrandy, A., Princen, S. and Segers, M. (2019) 'Rethinking the European Social Market Economy: Introduction to the Special Issue', Journal of Common Market Studies, 57(1): 3-12.

Clark, A. and Bennie, L. (2018) 'Parties, mandates and multilevel politics:Subnational variation in British general election manifestos', Party Politics, 24(3): 253-64.

Community Foundation Network (2009) Manifesto for Community Philanthropists, London. DAFNE (2019), PRESS RELEASE: EUROPEAN PHILANTHROPY MANIFESTO CALLING FOR A SINGLE MARKET FOR PHILANTHROPY.

Eder, N., Jenny, M. and Müller, W. C. (2017) 'Manifesto functions: How party candidates view and use their party's central policy document', Electoral Studies, 45: 75-87. European Commission (2009), Commission consults on a possible European Foundation Statute. 
Harrow, J and Jung, T, The European Philanthropy Manifesto: 'clearly needed and a very good thing'?, - post-peer-review preprint authors' version accepted for publication in Voluntary Sector Review

European Commission (2012) Proposal for a Council Regulation on the Statute for a European Foundation. COM(2012) 35 final 2012/0022 (APP): Brussels.

European Commission (2013), REGULATION (EU) No 576/2013 OF THE EUROPEAN

PARLIAMENT AND OF THE COUNCIL of 12 June 2013 on the non-commercial movement of pet animals and repealing Regulation (EC) No 998/2003. EU, Official Journal of the European Union.

European Commission Directorate-General for Research and Innovation (2018) Driving Progress for Research and Innovation in Europe: the potential of R\&I foundations, Brussels: European Union.

European Foundation Centre (2014), European Commission halts negotiations on the European Foundation Statute - What's next? , Press Release.

European Venture Philanthropy Association (ND) POLICY BRIEF. The New EU Multiannual Financial Framework 2021-2027.

Fondation de Franceand Centre d'Étude et de Recherche sur la Philanthropie (2015) An overivew of philanthropy in Europe.

Han, J. (2017) 'Social Marketisation and Policy Influence of Third Sector Organisations:

Evidence from the UK', VOLUNTAS: International Journal of Voluntary and Nonprofit Organizations, 28(3): 1209-25.

Harmel, R., Tan, A. C., Janda, K. and Smith, J. M. (2018) 'Manifestos and the "two faces" of parties:Addressing both members and voters with one document', Party Politics, 24(3): 278-88.

Harrow, J. and Jung, T. (2015) 'Debate: Thou shalt have impact, total impact - government involvement in philanthropic foundations' decision-making ', Public Money \& Management, 35(3): 176-78.

Hartnell, C. and Milner, A. (2015) 'Rejection of European Foundation Statute a 'missed opportunity", Alliance, March.

Hopt, K. J., von Hippel, T., Anheier, H., Then, V., Ebke, W., Reimer, E. and Vahlpahl, T. (2008) Feasibility Study on a European Foundation Statute: Centre for Social Investment and Max Planck Institute for Comparative and International Private Law.

IUPUI Indiana University Lilly Family School of Philanthropy (2018) The Global Philanthropy Environment Index 2018. European Edition. 
Harrow, J and Jung, T, The European Philanthropy Manifesto: 'clearly needed and a very good thing'?, - post-peer-review preprint authors' version accepted for publication in Voluntary Sector Review

Johnson, P. D. (2018) Global Philanthropy Report: Hauser Institute for Civil Society and the Center for Public Leadership.

Jung, T. (2019), The European Philanthropy Manifesto: some critical comments. Alliance.

Jung, T. and Harrow, J. (2019) 'Providing Foundations. Philanthropy, Global Policy, and Administration', in D. Stone andK. Moloney (eds), The Oxford Handbook of Global Policy and Transnational Administration, Oxford, Oxford University Press. pp. 619-37. Jung, T., Harrow, J. and Leat, D. (2018) 'Mapping Philanthropic Foundations' Characteristics: towards an international integrative framework of foundation types', Nonprofit and Voluntary Sector Quarterly, 47(5): 893-917.

Kabir, S. and Stirrat, R. L. (2018) 'Philanthropy, Remittances and Identity: The Case of London-based Sri Lankans', Society and Culture in South Asia, 4(1): 44-63.

Klüver, H. (2013) Lobbying in the European Union: interest groups, lobbying coalitions and policy change, Oxford: Oxford University Press.

McGee, A. and Weatherill, S. (1990) 'The Evolution of the Single Market: Harmonisation or Liberalisation', The Modern Law Review, 53(5): 578-96.

McGrath, C. (2007) 'Framing lobbying messages: defining and communicating political issues persuasively', Journal of Public Affairs, 7(3): 269-80.

Moosmann, K. (2007) 'The European Foundation - a new concept is born', Trusts \& Trustees, 13(5): 128-34.

Moss, G. (2014) European Foundation Statute suffers setback, https://www.ipe.com/news/regulation/european-foundation-statute-sufferssetback/10005189.fullarticle.

Nickel, P. M. and Eikenberry, A. M. (2009) 'A Critique of the Discourse of Marketized Philanthropy', American Behavioral Scientist, 52(7): 974-89.

Nillsson, S. (2012) 'Opinion of the European Economic and Social Committee on the 'Proposal for a Council Regulation on the Statute for a European Foundation (FE)'. $\operatorname{COM}(2012) 35$ final - 2012/0022 (APP). 2012/C 351/12', Official Journal of the European Union.

Pelkmans, J. (2016) 'Why the single market remains the EU's core business', West European Politics, 39(5): 1095-113. 
Harrow, J and Jung, T, The European Philanthropy Manifesto: 'clearly needed and a very good thing'?, - post-peer-review preprint authors' version accepted for publication in Voluntary Sector Review

Perez, M. (2019) 'Transaction Cost Perspectives on Cooperation: A Study of Hybrids Through Foundations Lobbying in the EU', VOLUNTAS: International Journal of Voluntary and Nonprofit Organizations, 30(2): 408-21.

Philanthropy Advocacy (2019) European Philanthropy Manifesto, Brussels: Donors and Foundations Networks in Europe (DAFNE)

European Foundation Centre (EFC).

Ray, L. (2007) 'Validity of measured party positions on European integration: Assumptions, approaches, and a comparison of alternative measures', Electoral Studies, 26(1): 1122.

Rossi, R. (2014) 'The Proposal for a European Foundation Statute and Its Influence on Italian Legislation', International Journal of Not-for-Profit Law, 16(1): 24-29.

Salole, G. (2013) 'If pets can move freely across EU borders, why can't philanthropy?', Philanthropy Impact Magazine, October.

Sandel, M. J. (2013) 'Market Reasoning as Moral Reasoning: Why Economists Should Reengage with Political Philosophy', Journal of Economic Perspectives, 27(4): 121-40.

Schlüter, A., Then, V. and Walkenhorst, P. (2001), Foundations in Europe. Society Management and Law. Bertelsmann Stiftung.

Sepi, M. (2010) 'Opinion of the European Economic and Social Committee on the 'European Foundation Statute' (own-initiative opinion) (2011/C 18/06)', Official Journal of the European Union, (19.1.2011): C18/30-18/34.

Smismans, S. (2003) 'European Civil Society: Shaped by Discourses and Institutional Interests', European Law Journal, 9(4): 473-95.

Thümler, E. (2016) 'Financialization of philanthropy: the case of social investment', in T. Jung, S. D. Phillips and J. Harrow (eds), The Routledge Companion to Philanthropy, London, Routledge. pp. 362-74.

Weible, C. M., Ingold, K., Nohrstedt, D., Henry, A. D. and Jenkins-Smith, H. C. (2019) 'Sharpening Advocacy Coalitions', Policy Studies Journal, 0(0). 